\title{
Polska Agencja Prasowa w systemie władzy publicznej
}

(6) https://doi.org/10.15633/9788363241131.02

Rozwój agencji informacyjnych to przede wszystkim skutek wprowadzania nowych technik łączności zapoczątkowanych przez telegraf. Ważne daty w dziejach tych instytucji to rok 1835, kiedy powstała agencja Havasa, czy rok 1851, gdy działalność rozpoczęła agencja Reutera. W Polsce pierwszą agencją prasową była Polska Agencja Telegraficzna założona w 1918 roku ${ }^{1}$.

Agencje informacyjne określane są tym mianem od końca xx wieku. Początkowo nazywano je agencjami telegraficznymi, a od połowy xx wie$\mathrm{ku}$ - agencjami prasowymi. Są to instytucje, które „gromadzą na potrzeby prasy, radia i telewizji i innych instytucji materiały informacyjne, publicystyczne lub dokumentalne w postaci mówionych i pisanych tekstów, obrazów i nagrań, dostarczane różnymi kanałami, przez korespondentów krajowych i zagranicznych, a także przez inne agencje prasowe na podstawie umów o współpracę. Agencje prasowe materiały te selekcjonują, opracowują merytorycznie i formalnie, redagują, niekiedy tłumaczą, a następnie rozsyłają odpłatnie prenumeratorom lub innym instytucjom w formie serwisów drogą radiową, dalekopisem, przez Internet, a niekiedy w postaci drukowanego biuletynu"2.

\footnotetext{
1 E. Ciborska, Polska Agencja Prasowa: tradycje i współczesność, „Rocznik Historii Prasy Polskiej” 1998, 1/1-2, s. 173.

2 Encyklopedia ksiązki, red. A. Żbikowska-Migoń, M. Skalska-Zlat, Wrocław 2017, s. 146.
} 
Kryteria charakteryzujące agencje informacyjne to między innymi rodzaj obsługiwanych mediów (mamy wtedy do czynienia z agencjami prasowymi, radiowymi, telewizyjnymi), ich status prawno-ekonomiczny (agencje mogą działać jako instytucje państwowe, spółki akcyjne z udziałem państwa, spółki wydawców i nadawców, spółdzielnie dziennikarskie ${ }^{3}$ czy też usytuowanie względem władz państwowych (agencje oficjalne reprezentujące stanowisko rządu, agencje półoficjalne reprezentujące stanowisko kół zbliżonych do rządu oraz tak zwane niezależne - powiązane z różnymi opcjami politycznymi i gospodarczymi) ${ }^{4}$.

Polska Agencja Prasowa, której status oraz istnienie ewentualnych zależności od władz państwowych są przedmiotem niniejszej analizy, funkcjonuje jako spółka akcyjna Skarbu Państwa. Podstawą jej działania jest ustawa o PAP z 1997 roku $^{5}$. W akcie prawnym znalazły się sformułowania wskazujące na dążenie do zapewnienia niezależności agencji. Będąc publiczną agencją prasową, otrzymała ona obowiązek uzyskiwania i przekazywania odbiorcom rzetelnej, obiektywnej i wszechstronnej informacji z kraju i zagranicy. Agencja nie może znaleźć się pod prawną, ekonomiczną lub inną kontrolą żadnego ugrupowania ideologicznego, politycznego i gospodarczego. Jako agencja publiczna ma za zadanie upowszechniać stanowiska Sejmu, Senatu, prezydenta i rządu, a także umożliwiać prezentowanie stanowisk innych naczelnych organów państwowych. Powyższy akt prawny uchwalony został z myślą o separacji PAP od bezpośrednich wpływów politycznych. Czy cel udało się osiągnąć? Aby odpowiedzieć na to pytanie, należy prześledzić aktywność rządzących podejmowaną wobec agencji.

\section{Początki Polskiej Agencji Prasowej}

Początki Polskiej Agencji Prasowej w Polsce komunistycznej to rok 1944. Wtedy to w Moskwie została powołana Polska Agencja Prasowa Polpress, która rok później dekretem Krajowej Rady Narodowej została przemia-

3 Tamże, s. 146.

4 Agencje prasowe, Encyklopedia Pwn, https://encyklopedia.pwn.pl/haslo/agencje-prasowe;3866265.html, 15.07.2021.

5 Ustawa z 31 lipca 1997 roku o Polskiej Agencji Prasowej, Dz.U. 1997, nr 107, poz. 687. 
nowana na Polską Agencję Prasową. Na podstawie tego dekretu agencja działała do 1983 roku. Na mocy ustawy o PAP z 1983 roku instytucja ta stała się jednostką rządową - zakładem budżetowym ${ }^{6}$.

Obecna PAP uważana jest za spadkobierczynię Polskiej Agencji Telegraficznej. Istniejąca w okresie międzywojennym agencja po II wojnie światowej kontynuowała swoją aktywność w Londynie. Agencja działała na emigracji do 1991 roku. W tymże roku bowiem doszło do podpisania symbolicznego aktu połączenia PAT oraz istniejącej w Polsce PAP. Od tego czasu PAP mogła świętować swoje kolejne rocznice długoletniego istnienia, przyjmując jako datę swojego powstania rok $1918^{7}$.

W państwie autorytarnym, jakim była PRL, nieuznającym praw wolnościowych, w tym wolności słowa czy wolności informacji, Polska Agencja Prasowa była traktowana instrumentalnie. Była ona faktycznie tubą informacyjno-propagandową rządzącej partii. Funkcjonowanie peerelowskiej PAP opisywał jej pierwszy szef w wolnej Polsce: „Liczne sita kontrolne, przez które musiała przedzierać się informacja, wraz z technicznymi zapóźnieniami Agencji sprawiały, że złośliwi odczytywali skrót PAP jako powolna agencja propagandowa" . $^{2}$

Rok 1989 w Polskiej Agencji Prasowej nie przyniósł większych zmian. Nadal jej prezesem, redaktorem naczelnym pozostawał - powołany jeszcze za czasów poprzedniego ustroju - Bogdan Jachacz. Początek przebudowy Polskiej Agencji Prasowej, będącej efektem transformacji ustrojowej, jaką ówcześnie przechodziła Polska, należy datować na jesień 1990 roku. Zadanie zreformowania tej instytucji otrzymał nowy jej szef Ignacy Rutkiewicz ${ }^{9}$. Renata Piasecka-Strzelec wymienia trzy podstawowe kierunki tych reform: zmiany kadrowe i w prowadzenie nowej polityki personalnej, wprowadzenie zasad warsztatowych odpowiadających standardom obowiązującym w państwach demokratycznych, zmiany technologiczne $\mathrm{w}$ zakresie odbierania i dystrybucji informacjami ${ }^{10}$. PAP ulegała przemia-

6 T. Mielczarek, Monopol, pluralizm, koncentracja. Środki komunikowania masowego w Polsce w latach 1989-2006, Warszawa 2007, s. 62.

7 R. Piasecka-Strzelec, Kierunki rozwoju agencji informacyjnych w Polsce po 1989 roku, „Rocznik Bibliologiczno-Prasoznawczy", tom 4/5, zeszyt 2, 2012, s. 61.

8 I. Rutkiewicz, Agencje prasowe - stare inowe, w: Media i dziennikarstwo w Polsce 1989-1995, red. G. G. Kopper, I. Rutkiewicz, K. Schliep, Kraków 1996, s. 78.

9 Tamże, s. 79.

10 R. Piasecka-Strzelec, Kierunki rozwoju, dz. cyt., s. 61. 
nom i modernizacji. Renata Piasecka-Strzelec ocenia, że pod koniec lat 90. PAP funkcjonowała już jako profesjonalna agencja: „Budowanie nowego wizerunku PAP, mimo licznych perturbacji, zakończyło się pełnym sukcesem. Zreformowana instytucja utrzymała status agencji oficjalnej oraz pozycję lidera na polskim rynku informacji agencyjnej, pozostając najważniejszą agencją informacyjną kraju"11.

\section{Polska Agencja Prasowa podporządkowana premierowi}

Polska Agencja Prasowa faktycznie pozostała największą agencją informacyjną w Polsce. Na możliwościach jej rozwoju i szansach na skuteczne reformy ciążyło jednak uzależnienie od wpływów politycznych. W pierwszym okresie II Rzeczpospolitej wpływy te były bezpośrednie, ponieważ działająca ciągle na podstawie ustawy z 1983 roku Polska Agencja Prasowa kierowana była przez prezesa - redaktora naczelnego powoływanego przez premiera. Podobnie jak w tym czasie doświadczała tego Telewizja Polska ${ }^{12}$, zmianom ekip rządzących towarzyszyły zmiany na stanowisku szefa PAP. Nowi premierzy odwoływali dotychczasowych prezesów PAP, aby powołać osobę im odpowiadającą ${ }^{13}$.

Po Ignacym Rutkiewiczu, którego popierał rząd Tadeusza Mazowieckiego, szefem PAP został Krzysztof Czabański powołany przez premiera Jana Olszewskiego, a po nim popierany przez premiera Waldemara Pawla$\mathrm{ka}$ - p.o. prezesa Michał Czarnecki ${ }^{14}$. Kolejni prezesi to ponownie Ignacy Rutkiewicz $^{15}$, Włodzimierz Gogołek ${ }^{16}$, Krzysztof Komornicki ${ }^{17}$.

11 Tamże, s. 62.

12 O personalnej karuzeli na stanowisku przewodniczącego Radiokomitetu na początku lat 9o. pisze Tomasz Mielczarek w książce Monopol, pluralizm, koncentracja, dz. cyt., s. 271.

13 Por. E. Ciborska, Polska Agencja Prasowa, dz. cyt., s. 185.

14 Tamże, s. 185.

15 Ignacy Rutkiewicz powrócił na stanowisko szefa PAP, ponieważ w tym czasie premierem została Hanna Suchocka. Jego rządy zakończyły się wraz z objęciem funkcji premiera ponownie przez Waldemara Pawlaka.

16 Włodzimierz Gogołek został prezesem PAP decyzją premiera Waldemara Pawlaka. Stanowisko stracił, gdy premierem został Włodzimierz Cimoszewicz.

17 J. Gaj, Ku niezależnościpolitycznej. Polska Agencja Prasowa wostatnipiętnastoleciu, „Studia Medioznawcze" 2007, $\mathrm{nr} 4$ (31), s. 125. 
Skutki tego rodzaju zależności między rządem a agencją informacyjną można dostrzec, śledząc ówczesne doniesienia medialne. Prasa donosiła między innymi o próbie ręcznego sterowania informacjami dostarczanymi przez PAP przez premiera Waldemara Pawlaka czy o konfliktach personalnych wewnątrz PAP, gdy szefem tej instytucji został Włodzimierz Gogołek mianowany przez Waldemara Pawlaka ${ }^{18}$.

\section{Ustawa o Polskiej Agencji Prasowej}

Reformy, które starano się wdrożyć w agencji informacyjnej w latach 9o., obejmowały także status formalno-prawny tej instytucji. Zmiany te miały zostać przeprowadzone poprzez uchwalenie odpowiednich regulacji prawnych. Chciano je zrealizować z myślą o przeciwstawieniu się bezpośredniemu uzależnieniu władz PAP od rządzącej ekipy. Na uchwalenie ustawy o PAP oraz wprowadzenie wyżej przedstawionych zapisów opisujących PAP jako instytucję, która nie może znaleźć się pod kontrolą żadnego ugrupowania ideologicznego, politycznego czy gospodarczego, trzeba było jednak długo czekać. Początkowe założenia mówiły o przekształceniu Polskiej Agencji Prasowej w jednoosobową spółkę akcyjną Skarbu Państwa, a następnie poprzez emisję akcji uczynieniu z niej własności mediów ${ }^{19}$. Taką treść prezentował projekt poselski z 1 lipca 1994 roku, wcześniej podobną koncepcję przygotował rząd Hanny Suchockiej ${ }^{20}$. W okresie rządów Socjaldemokracji Polskiej i PSL pojawiła się rządowa koncepcja, według której PAP miała stać się oddziałem Biura Prasowego Rządu, chociaż działającym w formie jednoosobowej spółki Skarbu Państwa. Szef rządu powoływałby radę nadzorczą PAP, a ta z kolei - prezesa PAP ${ }^{21}$. Odmienne wizje statusu PAP były przyczyną kolejnych przesunięć w zakończeniu reformowania tej instytucji. Ostatecznie ustawa o PAP została uchwalona 31 lipca $1997 \mathrm{roku}^{22}$. Na jej mocy PAP stała się spółką akcyjną Skarbu Państwa, która miała zostać sprywatyzowana, jednakże inaczej, niż to pierwotnie zakładano - nie w całości. Skarb Państwa za-

18 Por. tamże, s. 131, a także T. Mielczarek, Monopol, pluralizm, koncentracja, dz. cyt., s. 63.

19 I. Rutkiewicz, Agencje prasowe, dz. cyt., s. 82.

20 J. Gaj, Ku niezależności politycznej, dz. cyt., s. 129.

21 Tamże, s. 129.

22 Dz.U. 1997, $\mathrm{nr}$ 107, poz. 687. 
gwarantował sobie pakiet kontrolny. Tylko 49\% akcji miało być udostępnione innym podmiotom ${ }^{23}$.

Ustawa wprowadziła nową strukturę władz Polskiej Agencji Prasowej. Na czele miał stać zarząd liczący od jednego do trzech członków. Prezesa zarządu i jego pozostałych członków miała powoływać rada nadzorcza. Rada nadzorcza z kolei miała liczyć od pięciu do siedmiu osób i miała być powoływana przez walne zgromadzenie, czyli de facto przez ministra skarbu. Kadencja obu instytucji - określona w statucie PAP - wynosiła trzy lata.

Nowa forma funkcjonowania Polskiej Agencji Prasowej miała skutkować niezależnością tej instytucji. Kadencyjność zarządu oraz rady nadzorczej miała gwarantować stabilność władz, wyeliminowanie zmian w składzie personalnym tych organów w sytuacji zmiany formacji rządzącej.

\section{Upolitycznienie Polskiej Agencji Prasowej po reformie}

Nowe regulacje prawne dały możliwość wyłonienia nowych władz PAP. Pierwszym prezesem PAP powołanym na mocy ustawy o Polskiej Agencji Prasowej został Robert Bogdański. Regulacje nie uchroniły instytucji przed zarzutami o upolitycznienie. Rządy Roberta Bogdańskiego kojarzonego ze sprawującą ówcześnie władzę Aws oznaczały wymianę osób na najważniejszych stanowiskach w Polskiej Agencji Prasowej. Elżbieta Ciborska pisze: „Nowy zarząd PAP [...] przeprowadził zwolnienia grupowe około 40 doświadczonych dziennikarzy, których zastąpili ludzie «z klucza partyjnego» bez wykształcenia i znajomości języków obcych. Nie pokuszono się o sprawdzoną procedurę ogłoszenia konkursu na poszczególne stanowiska" ${ }^{24}$. W proteście przeciwko tym poczynaniom z PAP odeszła Anna Bogusz, która pracowała w tej instytucji od 1986 roku, między innymi kierując zespołem ekonomicznym i będąc zastępcą kierownika zespołu politycznego. Nowemu szefostwu zarzucała „manipulację informacjami w depeszach, brak obiektywizmu i służalczość wobec ekipy rządzącej”25.

23 Por. art. 7 ustawy z 31 lipca 1997 roku o PAP, Dz.U. 1997, nr 107, poz. 687.

24 E. Ciborska, Polska Agencja Prasowa, dz. cyt., s. 190.

25 J. Gaj, Ku niezależności politycznej, dz. cyt., s. 133. 
Robert Bogdański pełnił swoją funkcję do grudnia 2002 roku. Po nim pełniącym obowiązki prezesa, a następnie prezesem został Waldemar Siwiński (prezesem był od kwietnia 2003 roku).

Wraz z końcem jego rządów rozpoczął się czas niepewności w agencji ${ }^{26}$. Sytuacja ta była wynikiem działań, które podjęła nowa ekipa rządząca (po wyborach jesienią 2005 roku rządy objęło Prawo i Sprawiedliwość wraz z koalicjantami Samoobroną i Ligą Polskich Rodzin). W marcu 2006 roku minister skarbu jako walne zgromadzenie odwołał $\mathrm{z}$ rady nadzorczej jej przewodniczącego Jerzego Domańskiego, równocześnie powołując do tej rady trzy inne osoby. Jerzy Domański nie uznał tej decyzji, a dwaj członkowie rady, którzy zasiadali w radzie jeszcze przed zmianami dokonanymi przez ministra skarbu, zaskarżyli postanowienie tegoż ministra do Sądu Okręgowego w Warszawie, wskazując, że zgodnie z zapisami ustawy o Polskiej Agencji Prasowej nie jest możliwa zmiana składu rady nadzorczej przed upływem trzyletniej kadencji. Sąd Okręgowy nie przychylił się do tej interpretacji. Sąd Apelacyjny wyrokiem z 12 kwietnia 2007 roku uchylił postanowienie i unieważnił decyzję ministra skarbu dotyczącą zmian w składzie rady nadzorczej ${ }^{27}$. Jerzy Domański po ponad roku batalii sądowych mógł wrócić na stanowisko przewodniczącego rady nadzorczej PAP ${ }^{28}$.

W czasie, gdy Jerzy Domański czekał na prawomocny wyrok sądowy, rada nadzorcza, chociaż były wątpliwości co do jej legalności działania (w związku z odwołaniem jednego jej członka i powołaniem trzech innych), nie próżnowała. Wyłoniła nowy zarząd Polskiej Agencji Prasowej na czele z prezesem Piotrem Skwiecińskim. Zarząd ten działał od maja 2006 roku $^{29}$. Funkcjonował on jednak bez wpisu do Krajowego Rejestru Sądowego. Rejestracji odmówił Sąd Rejonowy w Warszawie. Chaos w PAP wywołany polityczną presją został zażegnany dopiero w lipcu 2007 roku. Rada nadzorcza z przewodniczącym Jerzym Domańskim przeprowadziła

26 T. Mielczarek, Monopol, pluralizm, koncentracja, dz. cyt., s. 64.

27 Komunikat w sprawie Nadzwyczajnego Walnego Zgromadzenia Akcjonariuszy, https:// www.money.pl/archiwum/wiadomosci_agencyjne/pap/artykul/komunikat;ws;nadzwyc zajnego;walnego;zgromadzenia;akcjonariuszy,228,0,238308.html, 18.07.2021.

28 Decyzją sądu Jerzy Domański jest przewodniczącym rady nadzorczej PAP-u, https://www. press.pl/tresc/8938,decyzja-sadu-jerzy-domanski-jest-przewodniczacym-rady-nadzorczej-pap-u, 18.07.2021.

29 J. Gaj, Ku niezależności politycznej, dz. cyt., s. 125. 
konkurs na prezesa i członków zarządu PAP. W wyniku legalnej procedury prezesem PAP został Piotr Skwieciński ${ }^{30}$.

W styczniu 2009 roku prezes Piotr Skwieciński podał się do dymisji. Powodem rezygnacji - jak pisał „Press” - „były rozbieżności pomiędzy zarządem PAP-u a radą nadzorczą, dotyczące działań zabezpieczających sytuację finansową agencji wobec kryzysu gospodarczego"31.

Przez półtora roku p.o. prezesa był Krzysztof Andracki, dotychczasowy przewodniczący rady nadzorczej. 30 lipca 2010 roku stanowisko szefa PAP objął Jerzy Paciorkowski. Pełnił swoją funkcję pełną kadencję do 31 lipca 2013 roku. Od tego momentu do 2016 roku PAP pozostawała bez prezesa. Zarząd agencji składał się ówcześnie z dwóch osób: Lidii Sobańskiej (członek zarządu do spraw handlowych) oraz Arkadiusza Szymanka (członek zarządu do spraw finansowych) ${ }^{32}$.

\section{Polska Agencja Prasowa jako medium narodowe}

9 maja 2016 roku prezesem PAP został Artur Dmochowski ${ }^{33}$. Został on wybrany na szefa agencji według dotychczasowych zasad, chociaż ówcześnie było już wiadomo, że Polską Agencję Prasową czekają radykalne zmiany. Po wyborach parlamentarnych jesienią 2015 roku władzę w Polsce przejęła koalicja partii, w której główną rolę odgrywało Prawo i Sprawiedliwość. Rządzący zapowiedzieli reformy mediów publicznych, które chcieli przekształcić w media narodowe. Nowymi regulacjami miała też zostać objęta Polska Agencja Prasowa, którą również chciano zaliczyć do owych mediów. Zmiany miały nastąpić na mocy ustawy o mediach narodowych. Projekt nowego aktu prawnego został przedstawiony Sejmowi 20 kwietnia 2016 roku $^{34}$.

30 Skwieciński ponownie prezesem PAP, https://www.wirtualnemedia.pl/artykul/skwiecinski-ponownie-prezesem-pap, 19.07.2021.

31 Wlutym konkurs na stanowisko prezesa PAP-u, https://www.press.pl/tresc/16o92,w-lutym-konkurs-na-stanowisko-prezesa-pap-u, 20.07.2021.

32 Odpowiedź ministra Skarbu Państwa na oświadczenie senatora Jana Marii Jackowskiego, https://www.senat.gov.pl/gfx/senat/userfiles/_public/k8/dokumenty/stenogram/oswiadczenia/jackowski/38020.pdf, 20.07.2021.

33 Artur Dmochowski nowym prezesem PAP, https://www.pap.pl/aktualnosci/ news\%2C513938\%2Cartur-dmochowski-nowym-prezesem-pap.html, 20.07.2021.

34 Projekt ustawy o mediach narodowych, druk nr 442, Warszawa 20 kwietnia 2016 roku. 
Koncepcja powołania mediów narodowych spotkała się z krytyką różnych środowisk. Sceptycznie wypowiadali się na ten temat badacze zajmujący się mediami. Podważano główne założenia reformy polegające na pozbawieniu Telewizji Polskiej, Polskiego Radia i PAP statusu jednoosobowych spółek akcyjnych Skarbu Państwa. W krytyce nie chodziło o uznanie tej formy istnienia mediów za najlepszą, ale o wskazanie, że zaproponowana forma instytucji mediów narodowych nie oferuje niczego skuteczniejszego w zarządzaniu mediami, a ponadto jest opisana w sposób mało precyzyjny. Jacek Sobczak argumentował, odnosząc się do projektu ustawy o mediach narodowych: „brak mi tak zwanych definicji legalnych. Mówimy o instytucjach mediów narodowych, dwie linijki dalej o narodowych instytucjach, mówimy o rozmaitych regulacjach, gdzie definicji brak. W uzasadnieniu stwierdza się, że te narodowe instytucje mają status, uwaga, zbliżony do instytucji kultury. To znaczy na ile zbliżony, czy tylko trochę zbliżony, czy może bardzo zbliżony, czy to są po prostu instytucje kultury"35.

Badaczom trudno było w tej koncepcji mediów narodowych dostrzec i zdefiniować pomysł autorów projektu ustawy o mediach narodowych na „nową” PAP. Jędrzej Skrzypczak zdobył się jedynie na stwierdzenie, że „tworzy się zupełnie nową strukturę, tj. instytucję mediów narodowych, która jednak ma dwie twarze. Z jednej strony narodowe instytucje radiofonii i telewizji, a z drugiej strony Polską Agencję Prasową"36.

W projekcie ustawy o mediach narodowych dużo miejsca zajęła kwestia misji publicznej. Jeden $\mathrm{z}$ artykułów stwierdza, że „instytucje pełnią misję publiczną". Mianem instytucji projekt określał nie tylko radiofonię i telewizję, lecz także Polską Agencję Prasową. Realizacja misji publicznej, obejmująca zatem również PAP, to między innymi: utrwalanie wspólnoty narodowej, umacnianie odpowiedzialności za dobro wspólne, wzbogacanie świadomości historycznej i przeciwdziałanie wypaczaniu obrazu historii Polski, ukazywanie wartości życia rodzinnego i działanie na rzecz umacniania rodziny ${ }^{37}$.

35 Stenogram z seminarium Krajowej Rady Radiofonii i Telewizji oraz Wydziału Dziennikarstwa i Nauk Politycznych Uniwersytetu Warszawskiego, 23 maja 2016 roku (materiał roboczy), http://www.archiwum.krrit.gov.pl/krrit/aktualnosci/news, 2314, naukowcy-o-projektach-ustaw-medialnych-prawa-i-sprawiedliwosci.html, 12.07.2021.

36 Tamże.

37 Por. Projekt ustawy o mediach narodowych, druk nr 442, Warszawa 20 kwietnia 2016 roku. 
Czy agencja informacyjna powinna mieć strategię bardzo wyraźnie nakierowaną na powyżej przedstawione cele? Są to - wydaje się - cele zbyt szczegółowe w odniesieniu do aktywności agencji informacyjnych, które - zgodnie z definicją - zajmują się gromadzeniem na potrzeby prasy, radia i telewizji i innych instytucji materiałów informacyjnych, publicystycznych lub dokumentalnych i wykonują to w sposób rzetelny i obiektywny.

Projekt zakładał zmianę struktury kierownictwa instytucji mediów narodowych. Na ich czele miał stać dyrektor powoływany przez Radę Mediów Narodowych. Chciano wyeliminować zatem obecne w spółkach akcyjnych Skarbu Państwa organy w postaci rad nadzorczych i zarządów.

Projekt ustawy o mediach narodowych postrzegany był jako efekt dążenia rządzących do podporządkowania sobie publicznej radiofonii i telewizji oraz agencji informacyjnej. Renata Piasecka-Strzelec pisze, że „postawił on pod znakiem zapytania niezależność PAP jako dostawcy bezstronnych i wiarygodnych informacji dla mediów w Polsce i za granicą"38.

Wśród wyrażających protest znalazło się także Europejskie Stowarzyszenie Agencji Informacyjnych (ESAI), wskazując, że koncepcja mediów narodowych, której realizacja dotyczy także PAP, faktycznie przybiera formę „represyjnych regulacji medialnych” i „ograniczy niezależność” PAP ${ }^{39}$.

Formacja rządząca ostatecznie zrezygnowała z przekształcenia mediów publicznych i PAP $\mathrm{w}$ instytucje mediów narodowych ${ }^{40}$. Do zarzuconego projektu już nie powróciła mimo początkowych zapowiedzi, że proces wprowadzania reform będzie wznowiony ${ }^{41}$.

38 R. Piasecka-Strzelec, Przeksztatcenia i zmiany w agencjach informacyjnych $w$ Polsce, „Studia Medioznawcze" 2016, nr 3, s. 101.

39 Europejskie Stowarzyszenie Agencji Informacyjnych protestuje przeciwko zmianom w PAP. „Wzywamy polski rzad”, https://wyborcza.pl/7,75399,19474379,europejskie-stowarzyszenie-agencji-informacyjnych-protestuje.html, 19.07.2021.

40 E. Olczyk, Kulisy gry o wptywy $w$ telewizji i radiu, https://www.wprost.pl/tygodnik/10009862/kulisy-gry-o-wplywy-w-telewizji-i-radiu.htm, 20.07.2021.

41 O tym, że wznowione zostaną prace nad reformą mediów publicznych, mówił w wywiadzie Krzysztof Czabański, zob. Rada Mediów Narodowych. Czabański: to jest bardzo ważna zmiana ustrojowa, https://www.money.pl/gospodarka/wiadomosci/artykul/rada-mediow-narodowych-czabanski-to-jest,169,0,2114473.html, 15.07.2021. 


\section{Rola Rady Mediów Narodowych w wyborze władz Polskiej Agencji Prasowej}

Nie zrezygnowano jednak z powołania Rady Mediów Narodowych - organu, który pierwotnie miał pełnić funkcję rady powierniczej ${ }^{42}$ społeczeństwa pilnującej realizacji misji publicznej w mediach narodowych. Nowa instytucja powstała na mocy ustawy o Radzie Mediów Narodowych uchwalonej 22 czerwca $2016 \mathrm{roku}^{43}$. Jej podstawowym zadaniem jest powoływanie i odwoływanie rad nadzorczych i zarządów Telewizji Polskiej, Polskiego Radia i Polskiej Agencji Prasowej (podmioty te nadal bowiem funkcjonują w niezmienionej formie jako spółki akcyjne Skarbu Państwa). Rada Mediów Narodowych jako organ decydujący o składzie zespołów kierujących mediami publicznymi i Polską Agencją Prasową wywołała krytykę chociażby z tego względu, że takie rozwiązanie wyeliminowało dwuetapowość w strukturze powoływania władz analizowanych podmiotów. Dotychczas stosowano zasadę, że radę nadzorczą powołuje organ zewnętrzny (w przypadku mediów - Krajowa Rada Radiofonii i Telewizji, w przypadku PAP - minister skarbu), a następnie to rada wyłania zarząd na czele z prezesem. Mechanizm ten dawał pewną szansę na niezależność instytucji, odseparowując zarząd od bezpośredniego wpływu organu zewnętrznego. Ponadto w przypadku mediów publicznych poprzednie regulacje zakładały przeprowadzenie konkursu do rad nadzorczych i jasno określały długość kadencji rad nadzorczych i zarządów.

Sprzeciw wzbudziło także odebranie kompetencji Krajowej Radzie Radiofonii i Telewizji w zakresie wpływania na skład rad nadzorczych TVP i PR. W grudniu 2016 roku Trybunał Konstytucyjny wydał wyrok, w którym pozbawienie Krajowej Rady Radiofonii i Telewizji owych kompetencji przejętych przez Radę Mediów Narodowych uznał za niezgodne z konstytucją ${ }^{44}$.

Rada Mediów Narodowych składa się z pięciu osób - trzech powoływanych przez Sejm, dwóch przez prezydenta. Jest wybierana na sześcioletnią

42 Tak nazwał Rmn Krzysztof Czabański, zob. Rada Mediów Narodowych. Czabański: to jest bardzo ważna zmiana ustrojowa, https://www.money.pl/gospodarka/wiadomosci/arty$\mathrm{kul} /$ rada-mediow-narodowych-czabanski-to-jest,169,0,2114473.html, 15.07.2021.

43 Ustawa z 22 czerwca 2016 roku o Radzie Mediów Narodowych, Dz.U. 2016, poz. 929.

44 Wyrok Trybunału Konstytucyjnego z 16 grudnia 2016 roku, sygn. akt K 13/16, Dz.U. 2016, poz. 2210. 
kadencję. Wybór członków do nowej instytucji został przeprowadzony w lipcu 2016 roku $^{45}$. W październiku 2016 roku Rada Mediów Narodowych zajęła stanowisko w sprawie zarządu PAP. Podjęła uchwałę, że zarząd będzie jednoosobowy (zostali zatem odwołani sprawujący funkcję członków zarządu PAP Lidia Sobańska i Arkadiusz Szymanek), a funkcję prezesa nadal będzie pełnił Artur Dmochowski. Rada Mediów Narodowych, która posiada także kompetencje $\mathrm{w}$ zakresie wprowadzania zmian w statutach TVP, PR i PAP, postanowiła, że ze statutu Polskiej Agencji Prasowej zostanie wykreślony dotychczasowy zapis o trzyletniej kadencji zarządu, a wprowadzona zostanie kadencja czteroletnia ${ }^{46}$. Artur Dmochowski miał zatem zasiadać w fotelu prezesa do 2020 roku. Swoją funkcję sprawował jednak tylko przez rok. 9 października 2017 roku został zawieszony przez Radę Mediów Narodowych, a trzy dni później sam złożył rezygnację, tłumacząc swoją decyzję brakiem porozumienia z radą nadzorczą PAP w sprawach finansowych. W doniesieniach medialnych pojawiły się jednak informacje o bliskim bankructwie PAP, do czego miał doprowadzić Artur Dmochowski. Prezes nie otrzymał absolutorium za $2017 \mathrm{rok}^{47}$.

Po Arturze Dmochowskim pełniącym obowiązki prezesa został Tomasz Giziński (oddelegowany z rady nadzorczej). W styczniu 2018 roku Rada Mediów Narodowych wybrała na prezesa PAP Wojciecha Surmacza. Drugim członkiem zarządu został Tomasz Przybek ${ }^{48}$.

W trakcie wyłaniania nowego zarządu dały o sobie znać podziały polityczne obecne w Radzie Mediów Narodowych. Instytucja ta - co jest efektem unormowań prawnych - prezentuje skład, w którym trzech członków jest związanych z PiS (wybrani przez Sejm), dwóch to przedstawiciele opozycji. Rada podejmuje decyzje większością głosów, zatem w praktyce

45 Por. Juliusz Braun i Grzegorz Podżorny będa członkami Rady Mediów Narodowych, https://wiadomosci.onet.pl/kraj/juliusz-braun-i-grzegorz-podzorny-beda-czlonkami-rady-mediow-narodowych/ntc5nz, 21.07.2021, oraz: Sejm wybrat członków Rady Mediów Narodowych. Opozycja: stworzyliście miejsca dla siebie, https://www.polsatnews.pl/wiadomosc/2016-07-22/sejm-wybral-czlonkow-rady-mediow-narodowych-opozycja-stworzyliscie-stanowiska-dla-siebie/, 21.07.2021.

46 RMN: zarząd PAP będzie jednoosobowy; prezesem Artur Dmochowski, https://www.pap. $\mathrm{pl} /$ aktualnosci/news\%2C $665971 \% 2 \mathrm{Crmn}$-zarzad-pap-bedzie-jednoosobowy\%3B-prezesem-artur-dmochowski.html, 22.07.2021.

47 R. Piasecka-Strzelec, W obliczu zmian. Agencje informacyjne w Polsce w latach 2016-2019, "Zeszyty Prasoznawcze” 2020, nr 4, s. 57.

48 Tamże, s. 57. 
to, czy dana uchwała zostanie przegłosowana, zależy od członków RMN kojarzonych z PiS.

W trakcie wyboru zarządu Polskiej Agencji Prasowej na początku 2018 roku kandydat, który zwyciężył, Wojciech Surmacz, został wcześniej zgłoszony przez przewodniczącego rady Krzysztofa Czabańskiego reprezentującego PiS (w tym czasie był posłem z ramienia tej partii). Przedstawiciel sejmowej opozycji Juliusz Braun - chociaż ze względu na polityczną konstrukcję rady nie mógł liczyć na powodzenie tej inicjatywy - zgłosił Romana Młodkowskiego. W kolejnych latach ze strony tegoż reprezentanta opozycji pojawiło się wiele propozycji uchwał. Były to jednak działania zwykle bez szans na ich przegłosowanie. Przykładem może być wniosek Juliusza Brauna z 2020 roku o odwołanie z funkcji prezesa PAP Wojciecha Surmacza. W lipcu tegoż roku na amerykańskim portalu ukazał się artykuł autorstwa prezesa PAP krytykujący Platformę Obywatelską i Rafała Trzaskowskiego. Prezes PAP wskazał wyraźnie, że w zbliżających się wyborach prezydenckich popiera Andrzeja Dudę. Juliusz Braun chciał odwołać Wojciecha Surmacza z powodu jego zaangażowania politycznego (reprezentuje on przecież instytucję, która nie może znaleźć się pod kontrolą jakiegokolwiek ugrupowania ideologicznego, politycznego lub gospodarczego). Nie mógł jednak nawet liczyć na to, że głosowanie zostanie przeprowadzone ${ }^{49}$.

Inne - wskazujące na brak politycznej niezależności Polskiej Agencji Prasowej - wydarzenie to wycofanie w sierpniu 2018 roku depeszy PAP z serwisu PAP Biznes ${ }^{50}$. Depesza zawierała informacje o krytyce, którą przedstawił prezes Narodowego Banku Polskiego w odniesieniu do projektu ustawy o pracowniczych planach kapitałowych przygotowanego przez ministerstwo finansów. Kierownictwo PAP nie podparło swojej decyzji żadnymi wyjaśnieniami. Autor depeszy po tym wydarzeniu zrezygnował $\mathrm{z}$ zatrudnienia w agencji ${ }^{51}$.

49 Juliusz Braun chce odwotania prezesa PAP, https://www.press.pl/tresc/62463,juliusz-braun-chce-odwolania-prezesa-pap, 12.07.2021.

50 R. Piasecka-Strzelec, W obliczu zmian, dz. cyt., s. 63.

51 PAP usunęła depesze, jej autor uznaje to za cenzuręi odchodziz agencji, https://www.press. $\mathrm{pl} /$ tresc/54148,pap-usunela-depesze_-jej-autor-uznaje-to-za-cenzure-i-odchodzi-z-agencji, 22.07.2021. 


\section{Problematyka prywatyzacji Polskiej Agencji Prasowej}

W rozważaniach na temat dążeń do upolitycznienia PAP, podporządkowania agencji celom partyjnym istotna jest także kwestia prywatyzacji tej instytucji.

Pierwotna koncepcja, o której pisał szef PAP Igor Rutkiewicz, wskazywała na to, że agencja ma zostać sprywatyzowana w taki sposób, aby stała się własnością mediów ${ }^{52}$. Tego rodzaju forma istnienia dawałaby szanse na największą niezależność. Tym samym Polska chciała pójść w ślady agencji zachodnich $^{53}$.

Zapisy ustawy o PAP uchwalonej w 1997 roku wskazywały już jednak na modyfikację tej koncepcji. W ustawie była mowa o prywatyzacji, ale $\mathrm{z}$ zastrzeżeniem, że „osobom trzecim nie można udostępnić więcej niż 49\% akcji, które nie mogą dawać więcej niż 49\% głosów na walnym zgromadzeniu" ${ }^{54}$. Skarb Państwa miał zatem posiadać większość udziałów w spółce.

Ustawa podawała także inne szczegóły dotyczące udostępniania akcji PAP osobom trzecim. Termin przeprowadzenia prywatyzacji miała określić w rozporządzeniu Rada Ministrów. Prywatyzacja jednak miała zostać przeprowadzona najwcześniej po upływie dwóch lat od daty wejścia w życie ustawy o PAP.

Tego rodzaju rozwiązanie dawało szanse na większą niezależność agencji. Przejęcie części akcji przez - jak się spodziewano - przedsiębiorstwa prasowe, radiowe lub telewizyjne dawało możliwość ograniczenia politycznych ingerencji.

W 2001 roku pojawiły się informacje ministerstwa skarbu o planach sprzedaży akcji. Według zapowiedzi prywatyzacja miała się zakończyć we wrześniu tego roku ${ }^{55}$. Według ówczesnych komentarzy rządzący - koali-

52 I. Rutkiewicz, Agencje prasowe, dz. cyt., s. 82.

53 DPA jest własnością mediów, państwo nie może mieć żadnych udziałów tej agencji. AFP zarządzają wspólnie przedstawiciele mediów oraz reprezentanci służb publicznych korzystający zusług agencji. Belgijska agencja Belga jest własnością gazet, podobnie duńska agencja Ritzau.

54 Ustawa z 31 lipca 1997 roku o PAP, Dz.U. 1997, nr 107, poz. 687.

55 BMF wybrany przez MSP na doradce przy prywatyzacji PAP, https://www.money.pl/gospodarka/wiadomosci/artykul/bmf;wybrany;przez;msp;na;doradce;przy;prywatyzacji;p ap;-;zrodlo,1,0,38913.html, 22.07.2021. 
cja SLD i PSL - stracili jednak zainteresowanie zmianami w agencji, kiedy skończyła się kadencja poprzedniego zarządu PAP i można było powołać „swoich ludzi”56. Przedsięwzięcie nie zostało zatem zrealizowane, a rządzący ponownie podjęli temat sprzedaży akcji dopiero w 2010 roku. Ówczesny wiceminister skarbu Adam Leszkiewicz zapowiadał, że prywatyzacja ma objąć całość spółki akcyjnej. Skarb Państwa miał zrezygnować z udziałów. Tego rodzaju koncepcja wymagała jednak najpierw nowelizacji ustawy o PAP ${ }^{57}$. Plany nie doszły do skutku, a możliwość sprzedaży akcji PAP w dotychczasowym kształcie zablokowała ustawa o Radzie Mediów Narodowych. Jej unormowania wprowadziły zmiany do ustawy o Polskiej Agencji Prasowej. Wykreślono zapis o udostępnianiu akcji osobom trzecim. Pojawiło się sformułowanie, że „Skarb Państwa zachowuje wszystkie akcje w Spółce" ${ }^{\text {58. }}$.

\section{Zakończenie}

Kiedy pod koniec 2001 roku coraz pewniejsze stawało się, że ówcześnie rządząca koalicja lewicowo-ludowa nie zamierza prywatyzować PAP, Krzysztof Kozłowski na łamach „Tygodnika Powszechnego” kierował ostrą krytykę w stronę ministra skarbu Wiesława Kaczmarka: „A to, że w krajach demokratycznych nie ma zazwyczaj rządowych (właścicielem PAP jest w tej chwili wyłącznie Ministerstwo Skarbu) agencji informacyjnych, bo z natury nie mogą być one obiektywne, dla ministra nie ma znaczenia. Widocznie myli biuro prasowe rządu $\mathrm{z}$ krajową agencją informacyjną" 59 .

Ustawa o Polskiej Agencji Prasowej z 1997 roku faktycznie niewiele zmieniła w kwestii jej niezależności od gremiów rządzących. Co prawda przestrzegane, aż do 2006 roku $^{60}$, unormowanie o braku możliwości

56 K. Kozłowski, Rządowa Agencja Prasowa, http://www.tygodnik.com.pl/numer/2751-52/ komentarze.html\#3, 24.07.2021.

57 Polska Agencja Prasowa na sprzedaż? MSP rozważa prywatyzację, https://www.newsweek. $\mathrm{pl} /$ polska-agencja-prasowa-na-sprzedaz-msp-rozwaza-prywatyzacje/7lp2wzp, 22.07.2021.

58 Por. art. 18 ustawa z 22 czerwca 2016 roku o Radzie Mediów Narodowych, Dz.U. 2016, poz. 929.

59 K. Kozłowski, Rządowa Agencja Prasowa, http://www.tygodnik.com.pl/numer/2751-52/ komentarze.html\#3, 24.07.2021.

6o Zapis ten został zmieniony w 2006 roku, kiedy minister skarbu odwołał z rady nadzorczej PAP Jerzego Domańskiego. 
odwołania członków rady nadzorczej PAP przed upływem kadencji było pewnym zabezpieczeniem stabilności rządów w agencji, ale niegwarantującym pełnej autonomii. Ciągle bowiem o obsadzie kierownictwa PAP decydował minister skarbu.

Rządzący nie byli zatem skorzy do sprzedaży części udziałów w spółce akcyjnej, jaką jest PAP, podmiotom zewnętrznym. Zaplanowana w ustawie o PAP prywatyzacja, w której - jak pierwotnie zakładano - miały uczestniczyć przedsiębiorstwa medialne, nie doszła do skutku. Polska pozostała więc państwem $z$ agencją informacyjną nadal podporządkowaną tylko rządowi, chociaż europejskie wzorce, które chciała naśladować, są zupełnie inne. Reuters jest spółką akcyjną notowaną na giełdzie. AFP działa $\mathrm{w}$ formie spółdzielni zarządzanej przez radę administracyjną, w której skład wchodzą przedstawiciele władz publicznych, ale oprócz nich są też przedstawiciele prasy, radia i telewizji. Czeska agencja čtк nie została sprywatyzowana, ale po przekształceniu jej w agencję publiczną podlega siedmioosobowej radzie wybieranej przez parlament ${ }^{61}$. Członkowie tej rady nie mogą być aktywni politycznie.

Od 2016 roku na skład rady nadzorczej i zarządu Polskiej Agencji Prasowej minister skarbu nie ma już wpływu. Władze PAP wybierane są przez Radę Mediów Narodowych. Nastąpiła jednak tylko pozorna separacja agencji od wpływów rządowych. Członkowie RMN nie tworzą apolitycznego gremium. Unormowania konstytuujące ten organ pozwalają na powoływanie do rady osób będących posłami i senatorami. Nie było zamiarem Prawa i Sprawiedliwości, która to partia jest pomysłodawcą tej nowej instytucji, uczynić z niej radę złożoną z fachowców zajmujących się mediami lub radę autorytetów.

61 J. Gaj, Ku niezależności politycznej, dz. cyt., s. 127. 